\title{
Az emberi térd, csípő és gerinc biomechanikai jellemzői, valamint terhelés hatására létrejött elváltozásainak áttekintő elemzése
}

\author{
2. rész: A térdízület biomechanikája
}

\section{An Overview of the Biomechanical Characteristics of the Human Knee, Hip and Spine, as well as the Changes Caused by Exercise}

Part 2 - Biomechanics of the Knee Joint

Cikksorozatom második részében a térdízület biomechanikai elemzését végzem. Irodalmi példákon fogom bemutatni, hogy a megnövekedett terhelés, testsúly, genetika és egyéb tényezők milyen nagy hatással vannak a térdpanaszok kialakulására. A kiképzéssel és bevetéssel járó megterhelés ellensúlyozására fontosnak tartom a megfelelő preventív szempontok alapján történő stratégia kialakítását, növelve ezáltal a kezelés hatékonyságának fokát, végeredményként pedig csökkentve a térdbetegségek kialakulásának kockázatát.

Kulcsszavak: térdízület, biomechanika, degeneratív betegség, térd arthrosis, keresztszalag sérülés

In the second part of my article series, I perform a biomechanical analysis of the knee joint. I will use examples from the literature to show what a significant effect increased load, body weight, genetics and other factors have on the development of knee complaints. To counterbalance the burden of training and deployment, 
I consider to develop a strategy based on appropriate preventive factors to be important, thereby increasing the effectiveness of treatment and ultimately reducing the risk of developing knee diseases.

Keywords: knee joint, biomechanics, degenerative disease, knee arthrosis, cruciate ligament injury

\section{Bevezetés}

Doktori kutatásomban az aktív katonai állomány mozgásszervi panaszait vizsgálom. Cikkemben szeretnék képet adni a térdízületet jellemző biomechanikai sajátosságokról és a túlterheléssel összefüggő problémák fontosságáról. Az anatómiai és biomechanikai ismeretek, valamint az egyes betegségek leírását csak a szükséges mértékben kívánom bemutatni, hangsúlyozva, hogy sem kutatásom, sem jelen írásom nem ezek részleteiben hivatott elmélyülni, ugyanakkor a könnyebb érthetőség kedvéért feltétlenül fontosnak tartom fentiek ismertetését. Bízom benne, hogy szakirodalmi példákkal alátámasztva szemléltetni tudom a probléma fontosságát, a prevenció és a hatékony, időben elkezdett kezelések szükségességét. Meggyőződésem, hogy megelőzéssel és korai, hatékony kezelésekkel a panaszok súlyosbodásának kockázata, valamint a panaszok megszünése után az aktív szolgálatba való visszatérés ideje csökkenthető.

\section{A térdízület anatómiája}

A térdízület 3 részböl álló, úgynevezett trochoginglymus ízület, amelyet a térdkalács és a combcsont közti (patellofemoralis) rész, valamint a belső és külső combcsont-lábszárcsont illeszkedő felszínei (medialis és lateralis femorotibialis) alkotnak. A combcsont térdízületet adó részének külső és belső felszínei (medialis és lateralis femurcondylusok) kisebb görbülettel rendelkeznek, mint a lábszárcsont ízfelszíneinek (tibiacondylusok) megfelelő vájulata, ezért csak kis felszínen érintkeznek egymással, és mozgás közben mind csúszó, mind pedig gördülő mozgást végeznek. ${ }^{2}$ Az ízületet szalagok stabilizálják. Az oldalszalagok - külső (lateralis) és belső (medialis) - az oldalirányú kitéréseket akadályozzák meg és így biztosítják a térd ilyen irányú stabilitását. A keresztszalagok (elülső és hátulsó keresztszalag) részt vesznek a térdízület oldalstabilizálásában, a lábszárcsont (tibia) elöre, illetve hátrafelé csúszásának megakadályozásában, valamint biztosítják a gördülö-csúszó mozgás tengelyét. ${ }^{3}$ Az ízületi porcfelszínek közti csúszó mozgás együtthatója 0,005 és 0,02 közötti értékben található, ami gyakorlatilag azt jelenti, hogy csúszó hatás szinte alig érvényesül. Ez az alacsony súrlódás rendkívül fontos a térdízület mechanikájában. ${ }^{4}$

A centrális stabilizáló elemeknek, a térdközi porcgyürünek (meniscusoknak) és a keresztszalagoknak nagyon fontos szerepük van térdünk biomechanikájában. A meniscusok

Szendrői Miklós (szerk.): Ortopédia. Budapest, Semmelweis, 2005. 355.

Szendröi (szerk.) (2005): i. m. 356

J. Charnley: The Lubrication of Animal Joints in Relation to Surgical Reconstruction by Artrhroplasty. Annals of Rheumatic Diseases, 19. (1960), 1. 10-19. 
az ízfelszínek közti téraránytalanságot csökkentik és a terhelési felületet növelik. Ezt szemlélteti az 1. ábra.

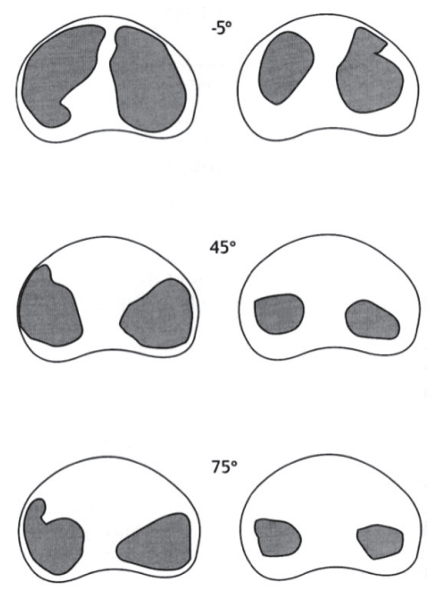

1. ábra

A meniscusok jelenléte és azok nélküli térdízületi érintkezési felszín sematikus ábrázolása a térd különbözö hajlitott helyzeteiben

A kép bal oldalán látható a meniscusok jelenlétében, jobb oldalon pedig azok hiányában kialakuló érintkezési felület. Látható, hogy a meniscusok milyen jelentős mértékben megnövelik az ízületben az érintkezési felszínt, ezáltal optimális nyomásviszonyokat hoznak létre.

Forrás: Brinckmann, Paul - W. Frobin - Gunnar Leivseth: Musculoskeletal Biomechanics. Stuttgart - New York, Thieme, 2002. 86.

A combcsont-térdkalács közti ízületben (patellofemoralis), ${ }^{5}$ a térdkalács és a szemben fekvő combcsont porcrésze közti érintkezési felszínen nincs teljes, a porcfelszín egészére kiterjedő érintkezés. ${ }^{6}$ Ezt a 2. ábra szemlélteti, ahol látható, hogy különböző hajlítási (flexio) tartományok során hol és milyen területen érintkezik a két porcfelszín egymással.

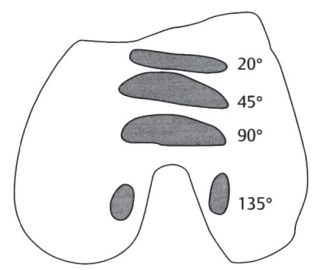

2. ábra

A patellofemoralis íület érintkezési felszíne a térdizület különböző hajlitottsági állapotában

A patellofemoralis izületben, a térd különböző hajlított helyzetében létrejövő érintkezési felszínek sematizálása során látható, hogy ebben az ízületrészben - 20, 45, 90 és 130 fokos helyzetben ábrázolva - a porc csak kis területére esik nyomás.

Forrás: Brinckmann-Frobin-Leivseth (2002): i. m. 87.

5 A patellofemoralis ízület térdünk külön tárgyalandó része, amelyet a betegségek, térdízületi panaszok, illetve biomechanikai jellemzők alapján is önálló entitásként kell kezelni.

6 B. B. Seedholm et al.: Mechanical Factors and Patellofemoral Osteoarthrosis. Annals of the Rheumatic Diseases, 38. (1979), 4. 307-316. 


\section{A térdízület biomechanikai összefüggései}

A térdízület fő mozgása a hajlítás és a nyújtás (flexio és extensio). Egészséges szalagrendszerrel rendelkező térdízületnél oldalirányú mozgás nincs, a hajlításon és nyújtáson kívül minden más irányba történő mozgathatóság kórosnak számít. A hajlítás (flexio) mértéke egyénenként változik, értéke körülbelül $130^{\circ}$.

A térdízület is kétkarú emelőként viselkedik, amelynek tengelye, a combcsont condylusai anatómiai kitüremkedéseinek összekötéséből (epicondylusok) adódó tengely. Azonban a forgástengely két oldalán két különböző nagyságú erő hat, különböző hosszúságú erőkarokkal, így csak abban az esetben tud megfelelően müködni, ha a két erő forgatónyomatéka egyenlő. A combcsont condylusainak föbb része a súlyvonal mögött helyezkedik el, a lábszárcsont ízfelszíne pedig a vízszinteshez képest 5-7 fokban lejt. Ez a helyzet azt biztosítja, hogy a járás bizonyos fázisában a combcsont ne csússzon elöre a lábszárcsont ízületi felszínén.

Az anatómiai részben is említettük, de fontossága miatt szeretném megint hangsúlyozni, hogy térdünk megfelelö mozgásához a térdízület szalagrendszerének épsége elengedhetetlen, azok stabilizáló szerepe nélkül megbomlik a normál biomechanikai egység.

Mérések alapján a térd forgástengelye nem állandó tengely, hanem folyamatosan változik a különböző hajlítottsági tartományokban. Ezen változásokra a 3. ábra mutat példát. ${ }^{8}$

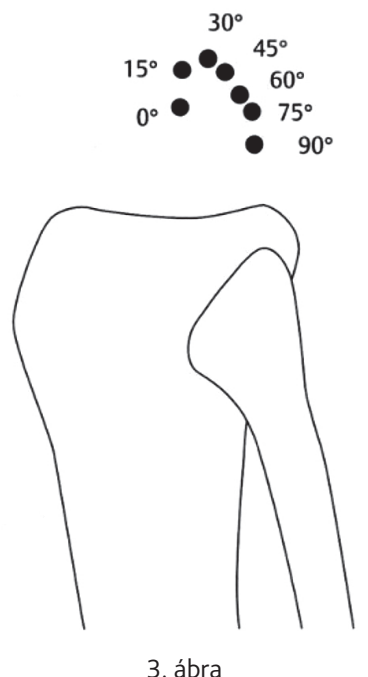

Különbözö mértékü flexionál a térdízület forgástengelyének elhelyezkedése

$0,15,30,45,60,75,90$ fokos flexio esetén a térd forgástengelyének sematikus ábrázolása.

Forrás: Brinckmann-Frobin-Leivseth (2002): i. m. 88.

Szendröi (szerk.) (2005): i. m. 356.

8 Gary L. Smidt: Biomechanical Analysis of Knee Flexion and Extension. Journal of Biomechanics, 6. (1973), 1. 79-92. 
A csúszó-gördülő mozgás kivitelezéséhez nagyon jól megalkotott biomechanikai összhang szükséges, amelyet részben a csontok anatómiai kialakulása, részben pedig a szalagok stabilizációja lát el. ${ }^{9}$ Menschik vizsgálatából tudhatjuk, hogy a flexio különböző fázisaiban, a keresztszalagok kereszteződési pontja adja a pillanatnyi rotációs tengelyt abból adódóan, hogy a keresztszalagok hossza állandónak tekinthető. Ha az oldalszalagok által meghatározott rotatios tengelyt is megvizsgáljuk, akkor látni fogjuk, hogy a pillanatnyi rotációs centrumot ez a tengely szintén keresztezi flexio folyamán. ${ }^{10}$ Ennek szemléltetésére a 4 . és 5 . ábra szolgál.

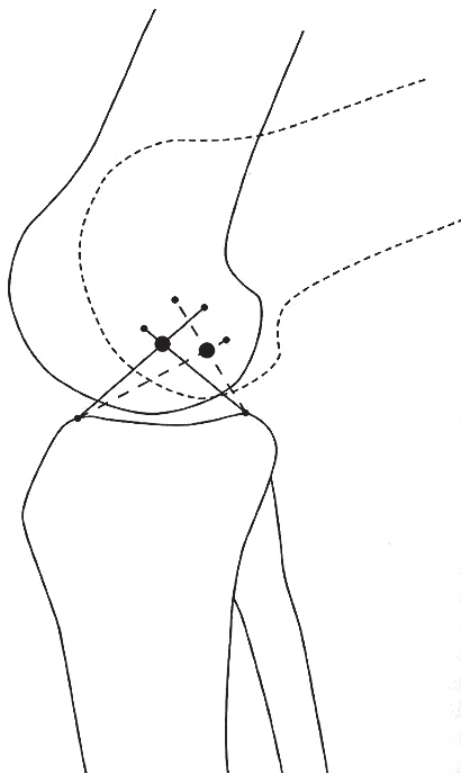

4. ábra

A keresztszalagok által kialakitott rotációs tengely A keresztszalagok által „vezetett” rotációs központ változása.

Forrás: Brinckmann-Frobin-Leivseth (2002): i. m. 88.

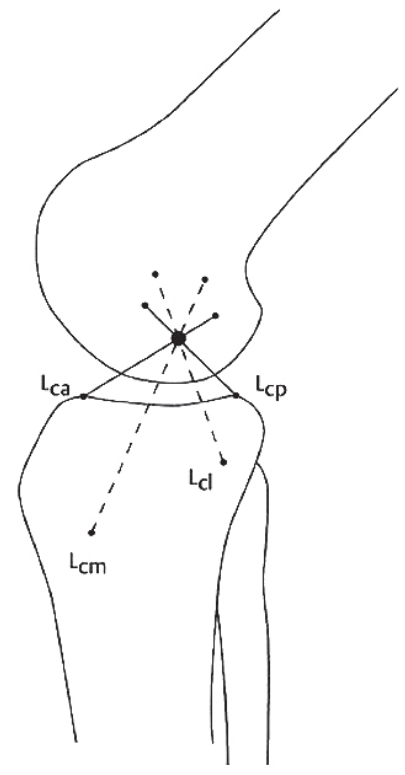

5. ábra

Az oldalszalagok által meghatározott rotációs tengely viszonya a keresztszalagok által meghatározott rotációs tengelyhez

Az aktuális, keresztszalagok által meghatározott forgáspont egybeesik az oldalszalagok rotációs pontjával egészséges biomechanikai és anatómai helyzet esetben. $L_{c a}$ : elülső keresztszalag (ligamentum cruciatum anterius); $\mathrm{L}_{c \mathrm{a}}$ : hátulsó keresztszalag (ligamentum cruciatum posterius); $\mathrm{L}_{\mathrm{cm}}$ belső oldalszalag (ligamentum collaterali tibiale); $\mathrm{L}_{\mathrm{c}}$ : lateralis oldalszalag (ligamnetum collaterale fibulare) Forrás: Brinckmann-Frobin-Leivseth (2002): i. m. 89.

9 A csontos anatómiai jellemzőre példa a lábszárcsont ízfelszínének 5-7 fokos hátrafelé irányultságú lejtése, valamint, hogy a combcsont condylusainak föbb része a súlyvonal mögött helyezkedik el.

10 A. Menschik: Mechanik des Kniegelenks. Teil 1. Z. Orthop, 112. (1974), 448-495. 
Fuss tanulmányában tovább finomította a korábbi méréseket és megállapította, hogy flexio során csak a keresztszalagok egy része kerül feszültség alá. ${ }^{11}$ Woo és munkatársai szerint az életkor előrehaladtával a keresztszalagok erőbíró képessége gyengül. ${ }^{12}$ Piazza és Cavanagh vizsgálata pedig nyilvánvalóvá tette, hogy a térd extensiója során, annak az utolsó 20 fokos tartományában, a tibia a hossztengelye mentén egy körülbelül 15 fokos kifordulást (kirotatiot) hajt végre a nem pontosan illeszkedő ízületifelszín-egyezés (kongruencia) miatt. ${ }^{13}$ A korábbi kutatások mérési eltéréseit is ezzel a mozgásjelenséggel magyarázta.

Látható, hogy térdünk egyszerűnek tűnő mozgása során - amelyet külső szemlélőként hajlítás-nyújtás váltakozásaként írhatunk le - tulajdonképpen csúszó-gördülö-forduló mozgás jelenik meg. Térdünk müködése elengedhetetlen életmódunkban, hiszen helyváltoztató mozgásunk egyik fő terhelő ízülete. Azonban vizsgálatakor a terhelés mértékétől, illetve az erőbehatásoktól függően kell értelmezni az alap biomechanikai összetevőket, hiszen a térdpanaszok kialakulásában, különösen a túlterhelődéssel járó betegségek megjelenésében, ezeknek van hatalmas szerepe.

A térdízület terhelésére jellemző, hogy a benne fellépő nyomás a térd hajlított állapotától is függ. A testre ható gravitációs erő erőkarja a térdízület forgó központjához viszonyítva majdnem nulla nyújtott térdízület és egyenes testtartás esetén, majd fokozatosan nő a térd hajlítása során. A gravitációs erő centruma hajlított térdízülettel történő állásnál az előlábat terheli, a térdhez viszonyítva pedig a térdízülettől hátrébb elhelyezkedő síkban (posterior) helyezkedik el, ahogy azt a 6. ábra is mutatja.

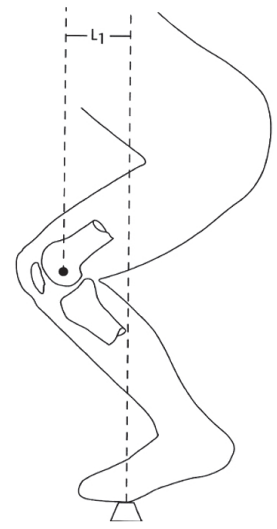

6. ábra

A gravitációs központ helyzete a térdhez viszonyitva hajlitott térddel való állás esetén $\mathrm{L}_{1}$ : a gravitációs erő erőkarja. A térd hajlítottsági állapotától függően, nyújtott törzs esetén változik a törzsre ható gravitációs erő erőkarja.

Forrás: Brinckmann-Frobin-Leivseth (2002): i. m. 91.

11 Franz K. Fuss: Anatomy of the Cruciate Ligaments and Their Function in Extension and Flexion of the Human Knee Joint. American Jorunal of Anatomy, 184. (1989), 2. 165-176.

12 Savio L. Woo et al.: Tensile Properties of the Human Femur-Anterior Cruciate Ligament-Tibia Complex: The Effects of Specimen Age and Orientation. The American Journal of Sports Medicine, 19. (1991), 3. 217-225.

13 Stephen J. Piazza - Peter R. Cavanagh: Measurement of the Screw-Home Motion of the Knee is Sensitive to Errors in Axis Alignement. Journal of Biomechanics, 33. (2000), 8. 1029-1034. 
Az egyensúlyi helyzetet ebben a hajlított térdízülettel történő helyzetben a quadriceps izom biztosítja, amely egy fontos ínnal tapad a lábszárcsont tuberositasán. Itt szeretném megemlíteni a térdkalácsunk (patella) kialakulásának fontosságát. Mérésekkel igazolták, hogy ha nem lenne jelen a patella, akkor nagyobb izomerő kellene a megfelelő egyensúlyi helyzet kialakításához az ín lefutása miatt. A térdkalács megfelelő helyzete tehát fontos az izommüködés és a térd biomechanikája szempontjából, hiszen befolyásolja a térdben ható erőket. ${ }^{14} \mathrm{~A}$ patella és combcsont közti ízületben a porcra ható erők eloszlanak a két ízületi felszín közt, és a térdízület hajlított állapotától függően más értéket mutatnak, amely erőnagyság az erőbehatás időtartamától is függ. ${ }^{15}$ Ez annak a következménye, hogy hosszabb időtartamú nyomás fennállása esetén a porcszövetben kis mértékben deformálódik, emiatt pedig az érintkezési felszín növekszik. ${ }^{16}$ A femoropatellaris ízületben végzett vizsgálatok egy részénél a porc alatti csontállomány sürüségét (densitását) is vizsgálták és azt találták, hogy ebben a régióban megnövekedett a csont sürüsége. ${ }^{17}$ A térdkalács alatti ín (ligamentum patellae) irányával szintén összefüggést mutat a patellofemoralis ízületben fellépő erőnagyság. Az ín iránya ráadásul a lábszárcsont mozgás közbeni rotációja miatt relatívnak tekinthető a combcsonthoz viszonyítva, hiszen az elfordulás közben a térben leírható módon változik. ${ }^{18}$

Ebből a korántsem teljes képből is látható, hogy a térdízület mozgása nagyon bonyolult folyamat. A térdben fellépő erőhatások számos, együttesen fellépő hatás eredőjeként jönnek létre, amely folyamatban bármiféle eltérés kóros mozgást és ennek következtében betegségek, panaszok kialakulását eredményezheti. Nagyon fontos annak vizsgálata - a megelőzés szempontjából és a kezelési stratégiák kialakítása miatt egyaránt -, hogy mozgásszervrendszerünk milyen anatómiai, biomechanikai eltéréseket mutat, valamint, hogy ezen eltérések milyen hatással vannak a tünetek megjelenésére. A normál mozgás, az erőviszonyok és a biomechanikai jellemzők megismerése, valamint a terhelés során fellépő erők, biomechanikai hatások vizsgálata elengedhetetlen a kóros folyamatok megértése szempontjából, hiszen - mozgásszervrendszerünket egy egységként tekintve - egymással összefüggő viszonyrendszerről van szó.

Fajunk alapvetően egységes anatómiával rendelkezik, azonban kijelenthetjük, hogy mozgásszerveink számos egyedi anatómiai variációt hordoznak. Véleményem szerint ezen „egyediség” miatt a terhelés sablonszerü alkalmazása - nélkülözve az egyedi anatómiai, biomechanikai jellemzők feltérképezését és figyelembevételét - megnöveli a túlterhelés kockázatát. Ezen írásomban a térdízület összefüggéseit vizsgáltam, föként annak biomechanikai változását megnövekedett terhelés esetén.

14 Paul Brinckmann - W. Frobin - Gunnar Leivseth: Musculoskeletal Biomechanics. Stuttgart - New York, Thieme, 2002. 90-97.

15 A. M. Ahmed - D. L. Burke - A. Yu: In-Vitro Measurement of Static Pressure Distribution in Synovial Joints. Part II: Retropatellar Surface. Journal of Biomechanical Engineering, 105. (1983), 3. 226-236; H. J. Hehne et al.: Eine neue Methode zur Ermittlung lastabhangiger Druck- und Kontaktverlaufe an Grenzflachen. Morphol Med., 1. (1981), 95-106; H. J. Hehne et al.: Analoge Druck- und Kontaktflachenmessung des Femoropatellargelenkes mit optisch sensibler Druckmessfolie. Z Orthop, 120. (1982), 513.

16 Brinckmann-Frobin-Leivseth (2002): i. m. 96-97.

17 M. Müller-Gerbl et al.: Die Darstellung der subchondralen Dichtemuster mittels der CT-Osteoabsortiometrie (CT-OAM) zur Beurteilung der individuellen Gelenkbeanspruchung am Lebenden. Z Orthop., 128. (1990), 128-133.

18 Brinckmann-Frobin-Leivseth (2002): i. m. 97. 
Zsákai Zsolt: Az emberi térd, csípő és gerinc biomechanikai jellemzői...

Az irodalmat áttekintve számos utalást találtam arra vonatkozólag, hogy a túlterhelés következtében fellépő változások milyen negatív hatást okoznak ebben az anatómiai régióban.

Wikstrom és munkatársai tanulmányában olvashatjuk, hogy a női populációban szignifikánsan növekedett értékű a csípő nyújtás (extensio) és a térdhajlítás (flexio), valamint ezzel ellentétben a térd extensiója kisebb végértéket mutat hölgyek esetében. A flexio és extensio során fellépő izomerő mértéke a férfi populációban mértekhez képest csökkentebb. A vizsgálatokból az is kiderült, hogy az egyensúlyi helyzet fenntartásában a nők jobbak, mert hölgyek esetén a gravitációs központra ható erő- és testtömegarány kisebb. Ugyanakkor a férfiak az egyensúlyi feladatok nehézségi szintjének növelésével javuló értékeket mutattak azokban az esetekben, amikor dinamikus testtartási stabilitással összefüggő gyakorlatokról volt szó. ${ }^{19}$

Katelyn és munkatársai kimutatták, hogy a BMI-értékek, valamint a testzsírszázalék értékei a nők esetén magasabbak, valamint, hogy ugrás során a talajérési fázisban a hölgyek esetében nagyobb csípő flexio és térd oldalirányú eltérés (valgisatio) tapasztalható. ${ }^{20}$

Witvrouw és munkatársai tanulmányukban azt vizsgálták, hogy a fokozottabb terhelésnek alávetett atlétikai sportolók közt milyen arányban fordul elő patella íngyulladás, bizonyos faktorok, mint a combizomzat-feszesség, izomerő, valamint bizonyos antropometriai változók jelenlétében. Azt találták, hogy a combizomzat csökkent rugalmassága (flexibilitás) szignifikánsan patella íngyulladáshoz vezet megterhelés esetén. ${ }^{21}$

Szintén Witvrouw és munkatársai munkájában találhatjuk meg, hogy a combizomzatot és térdízületet nagyobb megterhelésnek kitevő labdarúgók esetén a megnövekedett combizomzat-feszesség, magasabb rizikótényezőt jelent mozgásszervi sérülések kialakulásában. ${ }^{22}$

Egy másik tanulmányukban Witvrouw és munkatársai leírták, hogy atlétikai sportolóknál a combizomzat feszessége, a belső combizomzat reflex válaszidejének megváltozása, a hipermobilis térdkalács ${ }^{23}$ nagyobb kockázatot jelentenek az elülső térdfájdalmak kialakulásában. ${ }^{24}$

A professzionális sportolók, nehéz fizikai munkát végzők esetén végzett kutatások eredményei azért lehetnek az aktív katonai szolgálatot teljesítő állomány esetén is elfogadhatók - vagy legalábbis figyelemre méltók -, mert katonák esetén a mozgásszervrendszert érő megterhelések nyilvánvalóan nagyobbak, mint az átlag populációban. Ilyen irányú szakirodalmat kutatva például McWilliam és munkatársai

19 Erik A. Wikstrom et al:: Gender and Limb Differences in Dynamic Postural Stability during Landing. Clinical Journal of Sports Medicine, 16. (2006), 4. 311-315.

20 Katelyn F. Allison et al.: Musculoskeletal, Biomechanical, and Physiological Gender Differences in the US Military. US Army Medical Department Journal, (2015), 22-32.

21 Erik Witvrouw et al.: Intrinsic Risk Factors for the Development of Patellar Tendinitis in an Athletic Population. A Two-Year Prospective Study. The American Journal of Sports Medicine, 29. (2001), 2. 190-195.

22 Erik Witvrouw et al.: Muscle Flexibility as a Risk Factor for Developing Muscle Injuries in Male Professional Soccer Players. A Prospective Study. The American Journal of Sports Medicine, 31. (2003), 1. 41-46.

23 Hipermobilis patella: a normálistól nagyobb mértékben eltérő oldalirányú mozgathatósága térdkalácsunknak.

24 Erik Witvrouw et al.: Intrinsic Risk Factors for the Development of Anterior Knee Pain in an Athletic Population. A Two-Year Prospective Study. The American Journal of Sports Medicine, 28. (2000), 4. 480-489. 
munkájából kiderül, hogy szignifikáns összefüggés van bizonyos nehezebb fizikai megterheléssel járó munkák, professzionális sporttevékenységek és a térdpanaszok kialakulása közt. ${ }^{25}$ Deacon és munkatársai pedig a professzionális ausztrál labdarúgók esetén találtak vizsgálatuk során megnövekedett kockázatot a térd kopásának kialakulása szempontjából. ${ }^{26}$

Jordaan és munkatársa az alapkiképzésen részt vevő katonáknál vizsgálta a túlterheléses sérülések incidenciáját. Azt találták, hogy a legtöbb esetben a lábszárcsont stresszreakciója (stresszfájdalma) és a térdkalács környékén kialakult (patellofemoralis) fájdalom fordultak elő. Vizsgálatukból kiderült, hogy a sérülések több mint $80 \%$-a a térdet, lábszárat és a bokát érintette. ${ }^{27}$

Culvenor és munkatársai szerint a futási technika optimalizálása és a fizikai terhelés során viselt brace ${ }^{28}$ használata hatékonyan csökkenti a patellofemoralis fájdalom kialakulásának valószínüségét. ${ }^{29}$

Taanila és munkatársai közléséből tudjuk, hogy a katonai szolgálat idején, a 18-28 éves férfi katonák közt, a deréktájéki fájdalmak után az alsó végtagi fájdalmak fordultak elő leggyakrabban, valamint a visszatérően ismétlődő sérülések közül a hát és a térd sérülései jelentek meg a legnagyobb számban. ${ }^{30}$

Prodromos és munkatársai tanulmányukban leírták, hogy a kosárlabdázó és labdarúgó hölgyek esetén a férfiakhoz képest háromszor nagyobb valószínűséggel alakul ki elülsőkeresztszalag-sérülés. Kutatásukból kiderül, hogy röplabda esetén a kockázat e sérülés vonatkozásában alacsony. ${ }^{31}$

Reiman és munkatársai munkájából kiderül, hogy a csípőízület és annak mozgási, biomechanikai eltérései is a térdpanaszok és -sérülések kialakulásához vezethetnek. ${ }^{32}$ Ez a tény pedig rendkívül érdekes összefüggésre mutat rá. Véleményem szerint nem csak célzottan az adott ízület vizsgálata, hanem komplex mozgásszervi státuszfelmérés szükséges, hogy képet kapjunk a kockázat mértékéről. A prevenció során ezen összefüggések felmérése nélkülözhetetlen a megfelelő, hatásos eredmények elérése érdekében.

Fentebb említettem, hogy térdünk alapvető funkciója a helyváltoztatásban mutatkozik meg leginkább. Járás során a saroktámasztást követő, a járásciklus $10 \%$-át kitevő időszakban a csípőízületben hajlítás (flexio), közelítés (adductio) és befelé

25 D. F. McWilliams et al.: Occupational Risk Factors for Osteoarthritis of the Knee: A Meta-Analysis. Osteoarthritis and Cartilage, 19. (2011), 7. 829-839.

26 Adam Deacon et al.: Osteoarthritis of the Knee in Retired, Elite Australian Rules Footballers. Medical Journal of Australia, 166. (1997), 4. 187-190.

27 Gerhard Jordaan - Martin P. Schwellnus: The Incidence of Overuse Injuries in Military Recruits during Basic Military Training. Military Medicine, 159. (1994), 6. 421-426.

28 Rögzítő (A szerző véleménye: Ortopédsebészeti, szakmai szemlélet alapján egy egészséges ízület rögzítésének szükségessége megosztja a szakma képviselőit. Ennek kifejtése külön kutatás keretén belül érdekes eredménnyel kecsegtet.)

29 Adam G. Culvenor et al.: Is Patellofemoral Pain Preventable? A Systematic Review and Meta-Analysis of Randomised Controlled Trials. British Jorunal of Sports Medicine, 55. (2021), 7. 378-384.

30 Henri Taanila et al.: Musculoskeletal Disorders in Physically Active Conscripts: A One-Year Follow-Up Study in the Finnish Defence Forces. BMC Musculoskeletal Disorders, 10. (2009), 1. 1-11.

31 Chadwick C. Prodromos et al.: A Meta-Analysis of the Incidence of Anterior Cruciate Ligament Tears as a Function of Gender, Sport, and a Knee Injury-Reduction Regimen. Arthroscopy, 23. (2007), 12. 1320-1325.

32 Michael P. Reiman - Lori A. Bolgla - Daniel Lorenz: Hip Functions Influence on Knee Dysfunction: A Proximal Link to a Distal Problem. Journal of Sport Rehabilitation, 18. (2009), 1. 33-46. 
fordulás (rotatio) valósul meg. A flexio mértéke 0-2 fok az adductio és a befelé rotatio 10-15 fok. ${ }^{33}$ Ha nő az aktivitás mértéke - például futás esetén, vagy emelkedőn történő járáskor -, akkor a nemek közti összehasonlító vizsgálatokban szignifikáns eltéréseket találhatunk: a nőknél fokozódnak ezen értékek. Nagyobb mértékü csípő adductio, befelé rotatio a térd középpontját a lábhoz viszonyítva medializálja, azaz valgisalódik a térd. Ezen irányú hatás a szalagokra és a patellofemoralis ízületre ró nagyobb terhelést, ami kialakító tényezője lehet az elülső keresztszalag szakadásnak ${ }^{34}$ és patellofemoralis fájdalomnak. ${ }^{35}$ Hollman és munkatársai vizsgálatukban szintén azt igazolták, hogy a csípőízület túlzott mértékű addukciója az érintett oldali térd dinamikus valgisalódásához vezethet. ${ }^{36}$

Ha másik anatómiai síkból (sagittalis) ${ }^{37}$ vizsgáljuk az eredő erők alakulását, akkor azt látjuk, hogy ezek az erők a csípőízület előtt és a térdízület mögött hatnak, így mindkét ízületben flexiós hatást indukálnak. Ha ugrás során, a földet érés pillanatában törzsünk elöre hajlított állapotban van, akkor a csípő feszítő izmaira (extensorokra) hat nagyobb megterhelés, ha egyenes helyzetben van törzsünk, akkor pedig a térd extensorokra. ${ }^{38}$ Ebböl könnyen látható, hogy a négyosztatú combizomban (musculus quadriceps femoris) húzódás, a patella ínban ínrendellenesség (tendinopathia) alakulhat ki és jelenhet meg panasz formájában.

Járáskor, futáskor az eredő erők úgy alakulnak, hogy a térd medialis kompartmentjére nagyobb erő esik, mint a lateralisra, ezáltal pedig az ott lévő porc terhelése fokozódik. ${ }^{39}$ Mozgás során törzsünk helyzete, valamint a medence stabilitása fontos az alsó végtagi terhelés szempontjából. Egyes betegségekben vagy állapotokban a csípőtávolító izmok (abductorok) izomereje csökkent, ezért a támaszkodási fázisban az ellenoldali csípőt nem képesek megtartani, így az lebillen (Trendelenburg-jel). Ennek következménye, hogy a törzs súlypontja - a középponthoz viszonyítva - átkerül a lengö végtag felé, ez pedig a támaszkodó végtag kifelé hajló (varus) irányú eltérését fokozza, ami a belső (medialis) ízületi résben túlterhelést okoz. Elmondható tehát, hogy a megfelelő mértékű csípő abductor izomerő csökkenti az ellenoldali csípő arthrosisának kialakulási valószínüségét. ${ }^{40} \mathrm{~A}$ fenti esetben - de más okból kifolyólag is - az emberek törzsüket a támaszkodó oldal felé billentik ellensúlyozásképpen (kompenzatorikusan),

33 G. Simoneau: Kinesiology of Walking. In Donald A. Neumann (szerk.): Kinesiology of the Musculoskeletal System. St Louis, MO, Mosby Inc., 2002. 523-569.

34 Timothy E.Hewett et al.: Biomechanical measures of neuromuscular control and valgus loading of the Knee Predict Anterior Cruciate Ligament Injury Risk in Female Athletes: A Prospective Study. American Journal of Sports Medicine, 33. (2005), 4. 492-501.

35 Christopher M. Powers: The Influence of Altered Lowerextremity Kinematics on Patellofemoral Joint Dysfunction: A Theoretical Perspective. Journal of Orthopaedic E Sports Physical Therapy, 33. (2003), 11. 639-646.

36 John H. Hollman et al.: Relationships between Knee Valgus, Hip-Muscle Strength, and Hip-Muscle Recruitment during a Single-Limb Step-Down. Journal of Sport Rehabilitation, 18. (2009), 1. 104-117.

37 Nyílirányú.

38 E. B. Simonsen et al.: Mechanisms Contributing to Different Joint Moments Observed during Human Walking. Scandinavian Journal of Medicine E Science in Sports, 7. (1997), 1. 1-13; J. Troy Blackburn - Darin A. Padua: Sagittal-Plane Trunk Position, Landing Forces, and Quadriceps Electromyographic Activity. Journal of Athletic Training, 44. (2009), 2. 174-179.

39 C. R. Winby et al:: Muscle and External Load Contribution to Knee Joint Contact Loads during Normal Gait. Journal of Biomechanics, 42. (2009), 14. 2294-2300.

40 Alison Chang et al.: Hip Abduction Moment and Protection against Medial Tibiofemoral Osteoarthritis Progression. Arthritis \& Rheumatism, 52. (2005), 11. 3515-3519. 
ami szintén negatív következményekkel jár az érintett oldali térdben. Ilyenkor a térd valgisatiója fokozódik, visszahatásképpen pedig mindez a csípő abductorok erejének további csökkenését eredményezi. ${ }^{41}$

Látható, hogy a vizsgálatok egy része a nemek közti anatómiai, biomechanikai sajátosságokat kutatja. Az ilyen irányú kutatások eredményei azt támasztják alá, hogy a nemek közt különbséget nem tevő, egységesített edzésprotokoll megnövekedett kockázatot jelent a térd panaszainak és a sérülések kialakulását illetően. Célszerü olyan programok bevezetése, amelyek ezt az egyenlőtlen terhelést csökkentik és megadják a lehetőséget ezen kockázat mérséklésére. Kraemer és munkatársai vizsgálatából kiderül, hogy a nők esetén bevezetett fizikaierőnlét-növelő edzésprogram javította a hölgyek eredményeit a kiképzés során, így jobb teljesítményt értek el, mint a program nélküli esetekben. ${ }^{42}$

Showery és munkatársai az aktív szolgálatot teljesítő katonák esetén vizsgálta az elsődleges és másodlagos térdízületi arthrosis (térdízületi kopás) kialakulásának incidenciáját. Vizsgálatukból kiderült, hogy a magasabb katonai rang és életkor, a fekete rassz, valamint a légierőnél, illetve tengerészgyalogságnál történő szolgálat szignifikánsan növeli a térdkopás kialakulásának valószínűségét. Írásukban hangsúlyozták a megfelelő preventív eljárás kialakítását és bevezetését, a következményes térd osteoarthritis kialakulási valószínüségének csökkentése céljából. ${ }^{43}$

Murtha és munkatársai azt találták, hogy az ismétlődő térdtraumák okán kialakuló térdízületi kopás gyakori indikációja az 50. életkor alatti totál térdprotézis (TEP) beültetésének. Az elülsőkeresztszalag-sérülés, porckárosodás, meniscussérülés gyakran vezet korai porckopáshoz, amelynek súlyos, a karriert és a mindennapi életet is érintő következményei lehetnek. Az általuk vizsgált, TEP-beültetésen átesett esetek 74\%-ánál volt valamilyen, a térdet érintő sérülés. A leggyakoribb sérülés az elülsőkeresztszalag-sérülés volt, amely, ha meniscusszakadással is társult, jelentősen felgyorsította a TEP-beültetés szükségességét. A térdben kialakult károsodás, majd az azt követő TEP-beültetés, a katonai szolgálatot teljesítőknél nagy százalékban (55\%) jelentette a további szolgálatra alkalmatlannak történő nyilvánítását. ${ }^{44}$

Jiang és munkatársai tanulmánya szerint önmagában az elhízás, a megnövekedett $\mathrm{BMI}$ is fokozott kockázatot jelent a térdízületi kopás kialakulásában. ${ }^{45}$

Az elülsőkeresztszalag-sérülések vonatkozásában Magnussen és munkatársai is azt találták, hogy akik átestek keresztszalagpótláson, azoknál az átlag idő, amíg térdízületi TEP-implantációra került sor 25,7 év, az átlagéletkor pedig 58,1 év volt. ${ }^{46}$

41 Ronald K. Lawrence et al.: Influences of Hip External Rotation Strength on Knee Mechanics during Single-Leg Drop Landings in Females. Clinical Biomechanics, 23. (2008), 6. 806-813.

42 William J. Kraemer et al.: Effect of Resistance Training on Women's Strength/Power and Occupational Performances. Medicine and Science in Sports Exercise, 33. (2001), 6. 1011-1025.

43 James E. Showery et al.: The Rising Incidence of Degenerative and Posttraumatic Osteoarthritis of the Knee in the United States Military. The Journal of Arthroplasty, 31. (2016), 10. 2108-2114.

44 Andrew S. Murtha et al.: Total Knee Arthroplasty for Posttraumatic Osteoarthritis in Military Personnel Under Age 50. Journal of Orthopaedic Research, 35. (2016), 3. 677-681.

45 Liying Jiang et al.: Body Mass Index and Susceptibility to Knee Osteoarthritis: A Systematic Review and Meta-Analysis. Joint Bone Spine, 79. (2012), 3. 291-297.

46 R A. Magnussen et al.: Total Knee Arthroplasty for Secondary Osteoarthritis Following ACL Reconstruction: A Matched-Pair Comparative Study of Intra-Operative and Early Post-Operative Complications. Knee, 19. (2012), 4. 275-278. 
Az elülsőkeresztszalag-sérülések, valamint az egyéb sporttal kapcsolatos sérülések a katonák esetén, a civil lakossághoz viszonyítva, tízszer gyakoribb előfordulást mutattak. ${ }^{47}$

Ahn és munkatársai munkájában olvashatjuk, hogy a katonai szolgálat idején elszenvedett elülsőkeresztszalag-sérülések az esetek 76,2\%-ában a katonai tevékenységhez, edzéshez, kiképzéshez voltak köthetők, 23,8\%-ban pedig egyéb napi elfoglaltság, például labdarúgás szerepelt kiváltó okként. Vizsgálatukból az is kiderül, hogy az adott tevékenység kezdetét követő 30 és 60 perc közti időablakban történtek a sérülések. ${ }^{48}$

Kaplan és munkatársai anatómiai és biomechanikai paraméterek (lábszár hossztengely, a lábszárcsont belső és külső ízfelszínének lejtése, a térd belső ízületi részének mélysége) vizsgálatával próbálták igazolni, hogy különböző nehézségű felszereléssel történő talajra érkezés során a térd elülsőkeresztszalag-rendszerére ható erők csökkenthetők-e azáltal, ha a talajfogás pillanatában az egyének növelik a térd behajlításának mértékét. Azt találták, hogy a flexio növelése jó stratégia lehet az elülsőkeresztszalag-sérülés kockázatának mérséklésére. Munkájukban klinikai relevanciát is megfogalmaztak. Véleményük szerint is fenti anatómiai, biomechanikai paraméterek szürésével azonosíthatók lesznek azok a személyek, akik kiegészítő gyakorlatok bevezetésével csökkenteni tudják az alsó végtagi sérülések kockázatát. ${ }^{49}$

Természetesen katonák esetén a túlterhelés mellett a kiképzés során, illetve a harctéren szerzett sérülések is okozhatnak térdízületi problémákat. Rivera és munkatársai a civil lakossággal összehasonlítva vizsgálták a térdízületi kopás prevalenciáját térdtáji sérüléseket elszenvedett katonák esetén. Rámutattak, hogy a katonai szolgálat idején bekövetkezett, térdsérülések kapcsán kialakult térdarthrosis prevalenciája magasabb ebben a populációban. ${ }^{50}$

Stannard és munkatársa közleményéböl kiderül, hogy a Különleges Müveleti Erőknél szolgálók közt a leggyakoribb sérüléseknek a boka, térd és deréktájéki gerinc bántalmai bizonyultak. Vizsgálatuk szerint a sérülések 68\%-a kiképzés alatt alakul ki, amely során a fizikai tréning közben elszenvedett sérülések fordultak elő legnagyobb számban. ${ }^{51}$

A genetikai faktorok vizsgálata is azt mutatta, hogy bizonyos genetikai tulajdonságokkal rendelkező egyének nagyobb valószínüséggel válnak érintetté a térd degeneratív megbetegedéseinek vonatkozásában. ${ }^{52}$ Ezzel is magyarázható a nem fehér rasszoknál kialakult nagyobb kockázat ténye, amelyet részben genetikai okokkal, részben pedig az eltérő BMI-vel és csontsürüség-eltéréssel magyaráznak. ${ }^{53}$

47 Brett D. Owens et al.: Incidence of Anterior Cruciate Ligament Injury among Active Duty U.S. Military Servicemen and Servicewomen. Military Medicine, 172. (2007), 1. 90-91.

48 J. Ahn et al.: The Mechanism and Cause of Anterior Cruciate Ligament Tear in the Korean Military Environment. Knee Surgery \& Related Research, 31. (2019), 13.

49 Jonathan T. Kaplan et al.: Association Between Knee Anatomic Metrics and Biomechanics for Male Soldiers Landing with Load. American Journal of Sports Medicine, 48. (2020), 6. 1389-1397.

50 Jessica C. Rivera et al.: Posttraumatic Osteoarthritis Caused by Battlefield Injuries: The Primary Source of Disability in Warriors. Journal of the American Academy of Orthopaedic Surgeons, 20. (2012), Suppl 1. S64-69.

51 Joanne Stannard - L. Fortington: Musculosceletal Injury in Military Special Operatiopns Forces: A Systematic Review. BMJ Military Health, 167. (2021), 4. 255-265.

52 Marc C. Hochberg et al.: Genetic Epidemiology of Osteoarthritis: Recent Developments and Future Directions. Current Opinion in Rheumatology, 25. (2013), 2. 192-197.

53 Ana M. Valdes - Tim D. Spector: Genetic Epidemiology of Hip and Knee Osteoarthritis. Nature Reviews Rheumatology, 7. (2011), 1. 23-32; Kay Chapman - Ana M. Valdes: Genetic Factors in OA Pathogenesis. Bone, 51. (2012), 2. 258-264. 
A genetikai eltérések, testsúly, BMI, életkor figyelembevétele, az egyénre jellemző mozgásszervi anatómiai és biomechanikai jellemzők felmérése csökkentheti a kockázatot a későbbi térdpanaszok kialakulását tekintve. Ennek pozitív hatását célzó vizsgálatból (Dijksma és munkatársai) kiderül, hogy a mozgásszervi sérülések ellátása jelentős pénzügyi terhet jelent a költségvetésnek, ${ }^{54}$ ami megítélésem szerint sem elhanyagolható tényező. Dijksma és munkatársai egy másik kutatása alapján kijelenthetö, hogy lényeges és fontos annak a szemléletnek a kialakítása, amely - prevenció szempontjából - kedvezőbb kiképzési stratégiát követ. ${ }^{55} \mathrm{Glaviano}$ és munkatársai is arra a következtetésre jutottak, hogy az elülső térdfájdalom kialakulási kockázatának csökkentése érdekében a kutatások középpontjába kerülhetnek az intervenciós programok kidolgozását és a képzési követelmények felülvizsgálatát célzó vizsgálatok.$^{56} \mathrm{Az}$ időben elkezdett kezelések fontosságát szintén nem e cikk keretén belül szeretném kifejteni, de a megelőzéssel párhuzamosan szükséges lehet egy korai kezelési protokoll felállítása is. Young és munkatársai közleményükben azt vizsgálták, hogy az elülső térdfájdalmak esetén a korai mozgásterápia csökkenti e fájdalmak kialakulásának valószínúségét. Tanulmányukban ugyanakkor leírják, hogy a katonák ilyen panaszokkal az esetek 62,3\%-ában nem vettek igénybe kezelést, ami az időben elkezdett kezelés fontosságáról szóló felvilágosítás hatékonyságának növelését teszi szükségessé. ${ }^{57}$ Véleményem szerint az aktív katonai szolgálat megkezdése előtt szélesebb körben kellene meghatározni és szürni azokat a tényezőket, amelyek kockázatként szerepelhetnek a térdízületi problémák kialakulásában, mert a térdízület védelme fontos és meghatározó lehet nemcsak a panaszok megjelenése, hanem annak komplettálódása és az egyén későbbi élete, karrierje szempontjából is.

\section{Felhasznált irodalom}

Ahmed, A. M. - D. L. Burke - A. Yu: In-Vitro Measurement of Static Pressure Distribution in Synovial Joints. Part II: Retropatellar Surface. Journal of Biomechanical Engineering, 105. (1983), 3. 226-236. Online: https://doi.org/10.1115/1.3138410 Ahn, Joosuk - Byungseop Choi - Yong Seuk Lee - Ki Woung Lee - Jung Woo Lee - Beom Koo Lee: The Mechanism and Cause of Anterior Cruciate Ligament Tear in the Korean Military Environment. Knee Surgery \& Related Research, 31. (2019), 13. Online: https://kneesurgrelatres.biomedcentral.com/articles/10.1186/s43019019-0015-1

Allison, Katelyn F. - Karen A. Keenan - Timothy C. Sell - John P. Abt - Takashi Nagai - Jennifer Deluzio - Mark McGrail - Scott M. Lephart: Musculoskeletal, Biomechanical, and Physiological Gender Differences in the US Military. US

54 Iris Dijksma et al.: Epidemiology and Financial Burden of Musculosceletal Injuries as the Leading Health Problem in the Military. Military Medicine, 185. (2020), 3-4. e480-e486.

55 Iris Dijksma et al.: Exercise Programs to Reduce the Risk of Musculuskeletal Injuries in Military Personnel: A Systematic Review and Meta-Analysis. PMER, 12. (2020), 10. 1028-1037.

56 Neal R. Glaviano - Michelle C. Boling - John J. Fraser: Anterior Knee Pain Risk Differs Between Sex and Occupation in Military Tactical Athletes. Journal of Athletic Training, (2021), március 31.

57 Jodi L. Young et al.: Usual Medical Care for Patellofemoral Pain Does Not Usually Involve Much Care: 2-Year Follow-up in the Military Health System. Journal of Orthopaedic \& Sports Physical Therapy, 51. (2021), 6. 305-313. 
Zsákai Zsolt: Az emberi térd, csípő és gerinc biomechanikai jellemzői...

Army Medical Department Journal, (2015), 22-32. Online: https://pubmed.ncbi. nlm.nih.gov/26101903/

Blackburn, J. Troy - Darin A. Padua: Sagittal-Plane Trunk Position, Landing Forces, and Quadriceps Electromyographic Activity. Journal of Athletic Training, 44. (2009), 2. 174-179. Online: https://doi.org/10.4085/1062-6050-44.2.174

Brinckmann, Paul - W. Frobin - Gunnar Leivseth: Musculoskeletal Biomechanics. Stuttgart - New York, Thieme, 2002.

Chang, Alison - Karen Hayes - Dorothy Dunlop - Jing Song - Debra Hurwitz - September Cahue - Leena Sharma: Hip Abduction Moment and Protection against Medial Tibiofemoral Osteoarthritis Progression. Arthritis \& Rheumatism, 52. (2005), 11. 3515-3519. Online: https://doi.org/10.1002/art.21406

Chapman, Kay - Ana M. Valdes: Genetic Factors in OA Pathogenesis. Bone, 51. (2012), 2. 258-264. Online: https://doi.org/10.1016/j.bone.2011.11.026

Charnley J.: The Lubrication of Animal Joints in Relation to Surgical Reconstruction by Artrhroplasty. Annals of Rheumatic Diseases, 19. (1960), 1. 10-19. Online: https:// doi.org/10.1136/ard.19.1.10

Culvenor, Adam - G. Marienke van Middelkoop - Erin M. Macri - Kay M. Crossley: Is Patellofemoral Pain Preventable? A Systematic Review and Meta-Analysis of Randomised Controlled Trials. British Journal of Sports Medicine, 55. (2021), 7. 378-384. Online: https://doi.org/10.1136/bjsports-2020-102973

Deacon, Adam - Kay Crossley - Peter Brukner - Kim Bennell - Zoltan S. Kiss: Osteoarthritis of the Knee in Retired, elite Australian Rules Footballers. Medical Journal of Australia, 166. (1997), 4. 187-190. Online: https://doi.org/10.5694/j.1326-5377.1997. tb140072.x

Dijksma, Iris - Marga Bekkers - Bea Spek - Cees Lucas - Martijn Stuiver: Epidemiology and Financial Burden of Musculosceletal Injuries as the Leading Health Problem in the Military. Military Medicine, 185. (2020), 3-4. 1-5. e480-e486. Online: https://doi.org/10.1093/milmed/usz328

Dijksma, Iris - Ilgin G. Arslan - Faridi S. Etten-Jamaludin - Roy G. Elbers - Cees Lucas - Martijn M. Stuiver: Exercise Programs to Reduce the Risk of Musculuskeletal Injuries in Military Personnel: A Systematic Review and Meta-Analysis. PMER, 12. (2020), 10. 1028-1037. Online: https://doi.org/10.1002/pmrj.12360

Fuss, Franz K.: Anatomy of the Cruciate Ligaments and Their Function in Extension and Flexion of the Human Knee Joint. American Journal of Anatomy, 184. (1989), 2. 165-176. Online: https://doi.org/10.1002/aja.1001840208

Glaviano, Neal R. - Michelle C. Boling - John J. Fraser: Anterior Knee Pain Risk Differs Between Sex and Occupation in Military Tactical Athletes. Journal of Athletic Training, (2021), március 31. Online: https://doi.org/10.4085/1062-6050-0578.20 Hehne Hj. et al.: Eine neue Methode zur Ermittlung lastabhangiger Druck- und Kontaktverlaufe an Grenzflachen. Morphol Med., 1. (1981), 95-106.

Hehne Hj. et al.: Analoge Druck- und Kontaktflachenmessung des Femoropatellargelenkes mit optisch sensibler Druckmessfolie. Z Orthop, 120. (1982), 513.

Hewett, Timothy E. - Gregory D. Myer - Kevin R. Ford - Robert S. Heidt - Angelo J. Colosimo - Scott G. McLean - Antonie J. van den Bogert - Mark V. Paterno - Paul Succop: Biomechanical Measures of Neuromuscular Control and Valgus Loading 
of the Knee Predict Anterior Cruciate Ligament Injury Risk in Female Athletes: A Prospective Study. American Journal of Sports Medicine, 33. (2005), 4. 492501. Online: https://doi.org/10.1177/0363546504269591

Hochberg, Mark C. - Laura Yerges-Armstrong - Michelle Yau - Braxton D. Mitchell: Genetic Epidemiology of Osteoarthritis: Recent Developments and Future Directions. Current Opinion in Rheumatology, 25. (2013), 2. 192-197. Online: https:// doi.org/10.1097/BOR.0b013e32835cfb8e

Hollman, John H. - Barbara E. Ginos - Jakub Kozuchowski - Amanda S. Vaughn - David A. Krause - James W. Youdas: Relationships between Knee Valgus, Hip-Muscle Strength, and Hip-Muscle Recruitment during a Single-Limb Step-Down. Journal of Sport Rehabilitation, 18. (2009), 1. 104-117. Online: https://doi.org/10.1123/ jsr.18.1.104

Jiang, Liying - Wenjing Tian - Yingchen Wang - Jiesheng Rong - Chundan Bao - Yupeng Liu - Yashuang Zhao - Chaoxu Wang: Body Mass Index and Susceptibility to Knee Osteoarthritis: A Systematic Review and Meta-Analysis. Joint Bone Spine, 79. (2012), 3. 291-297. Online: https://doi.org/10.1016/j.jbspin.2011.05.015 Jordaan, Gerhard - Martin P. Schwellnus: The Incidence of Overuse Injuries in Military Recruits during Basic Military Training. Military Medicine, 159. (1994), 6. 421426. Online: https://doi.org/10.1093/milmed/159.6.421

Kaplan, Jonathan T. - John W. Ramsay - Sarah E. Cameron - Kayla D. Seymore - Michael Brehler - Gaurav K. Thawait - Wojciech B. Zbijewski - Jeffrey H. Siewerdsen - Tyler N. Brown: Association Between Knee Anatomic Metrics and Biomechanics for Male Soldiers Landing with Load. American Journal of Sports Medicine, 48. (2020), 6. 1389-1397. Online: https://doi.org/10.1177/0363546520911608

Kraemer, William J. - Scott A. Mazzetti - Bradley C. Nindl - Lincoln A. Gotshalk - Jeff S. Volek - Jill A. Bush - Jim O. Marx - Kei Dohi - Ana L. Gómez - Mary Miles Steven J. Fleck - Robert U. Newton - Keijo Häkkinen: Effect of Resistance Training on Women's Strength/Power and Occupational Performances. Medicine and Science in Sports and Exercise, 33. (2001), 6. 1011-1025. Online: https://doi. org/10.1097/00005768-200106000-00022

Lawrence, Ronald K. - Thomas W. Kernozek - Emily J. Miller - Michael R. Torry - Paul Reuteman: Influences of Hip External Rotation Strength on Knee Mechanics during Single-Leg Drop Landings in Females. Clinical Biomechanics, 23. (2008), 6. 806-813. Online: https://doi.org/10.1016/j.clinbiomech.2008.02.009

Magnussen, Robert A. - Guillaume Demey - Sébastien Lustig - Elvire Servien - Philippe Neyret: Total Knee Arthroplasty for Secondary Osteoarthritis Following ACL Reconstruction: A Matched-Pair Comparative Study of Intra-Operative and Early Post-Operative Complications. Knee, 19. (2012), 4. 275-278. Online: https://doi.org/10.1016/j.knee.2011.05.001

McWilliams, D. F. - B. F. Leeb - S. G. Muthuri - M. Doherty - W. Zhang: Occupational Risk Factors for Osteoarthritis of the Knee: A Meta-Analysis. Osteoarthritis and Cartilage, 19. (2011), 7. 829-839. Online: https://doi.org/10.1016/j.joca.2011.02.016 Menschik, Alfred: Mechanik des Kniegelenks. Teil 1. Z. Orthop., 112. (1974), 448-495. Military Environment. Knee Surgery E Related Research, 31. (2019), 13. Online: https:// doi.org/10.1186/s43019-019-0015-1 
Zsákai Zsolt: Az emberi térd, csípő és gerinc biomechanikai jellemzői...

Murtha, Andrew S. - Anthony E. Johnson - Joseph A. Buckwalter - Jessica C. Rivera: Total Knee Arthroplasty for Posttraumatic Osteoarthritis in Military Personnel Under Age 50. Journal Of Orthopaedic Research, 35. (2016), 3. 677-681. Online: https://doi.org/10.1002/jor.23290

Müller-Gerbl, M. et al.: Die Darstellung der subchondralen Dichtemuster mittels der CT-Osteoabsortiometrie (CT-OAM) zur Beurteilung der individuellen Gelenkbeanspruchung am Lebenden. Z Orthop., 128. (1990), 128-133. Online: https:// doi.org/10.1055/s-2008-1039487

Owens, Brett D. - Sally B. Mountcastle - Warren R. Dunn - Thomas M. DeBerardino - Dean C. Taylor: Incidence of Anterior Cruciate Ligament Injury among Active Duty U.S. Military Servicemen and Servicewomen. Military Medicine, 172. (2007), 1. 90-91. Online: https://doi.org/10.7205/MILMED.172.1.90

Piazza, Stephen J. - Peter R. Cavanagh: Measurement of the screw-home motion of the knee is sensitive to errors in axis alignement. Journal of Biomechanics, 33. (2000), 8. 1029-1034. Online: https://doi.org/10.1016/S0021-9290(00)00056-7

Powers, C. M.: The Influence of Altered Lowerextremity Kinematics on Patellofemoral Joint Dysfunction: A Theoretical Perspective. Journal of Orthopaedic E Sports Physical Therapy, 33. (2003), 11. 639-646. Online: https://doi.org/10.2519/ jospt.2003.33.11.639

Prodromos, Chadwick C. - Yung Han - Julie Rogowski - Brian Joyce - Kelvin Shi: A Meta-Analysis of the Incidence of Anterior Cruciate Ligament Tears as a Function of Gender, Sport, and a Knee Injury-Reduction Regimen. Arthroscopy, 23. (2007), 12. 1320-1325. Online: https://doi.org/10.1016/j.arthro.2007.07.003

Reiman, Michael P. - Lori A. Bolgla - Daniel Lorenz: Hip Functions Influence on Knee Dysfunction: A Proximal Link to a Distal Problem. Journal of Sport Rehabilitation, 18. (2009), 1. 33-46. Online: https://doi.org/10.1123/jsr.18.1.33

Rivera, Jessica C. - Joseph C. Wenke - Joseph A. Buckwalter - James R. Ficke - Anthony E. Johnson: Posttraumatic Osteoarthritis Caused by Battlefield Injuries: The Primary Source of Disability in Warriors. Journal of the American Academy of Orthopedic Surgeons, 20. (2012), Suppl 1. S64-69. Online: https://doi.org/10.5435/JAAOS-20-08-S64

Smidt, Gary L.: Biomechanical Analysis of Knee Flexion and Extension. J. Biomechanics, 6. (1973), 1. 79-92. Online: https://doi.org/10.1016/0021-9290(73)90040-7

Seedholm, B. B. - T. Takeda - M. Tsubuku - V. Wright: Mechanical Factors and Patellofemoral Osteoarthrosis. Annals of the Rheumatic Diseases, 38. (1979), 4. 307-316. Online: https://doi.org/10.1136/ard.38.4.307

Showery, James E. - Nicholas A. Kusnezov - John C. Dunn - Julia O. Bader - Philip J. Belmont Jr-Brian R. Waterman: The Rising Incidence of Degenerative and Posttraumatic Osteoarthritis of the Knee in the United States Military. The Journal of Arthroplasty, 31. (2016), 10. 2108-2114. Online: https://doi.org/10.1016/j.arth.2016.03.026

Simoneau, G.: Kinesiology of Walking. In Donald A. Neumann (szerk.): Kinesiology of the Musculoskeletal System. St Louis, MO, Mosby Inc., 2002. 523-569.

Simonsen, E. B. - P. Dyhre-Poulsen - M. Voigt - P. Aagaard - N. Fallentins: Mechanisms Contributing to Different Joint Moments Observed During Human Walking. Scandinavian Journal of Medicine E Science in Sports, 7. (1997), 1. 1-13. Online: https://doi.org/10.1111/j.1600-0838.1997.tb00110.x 
Stannard, Joanne - L. Fortington: Musculosceletal Injury in Military Special Operations Forces: A Systematic Review. BMJ Military Health, 167. (2021), 4. 255-265. Online: https://doi.org/10.1136/bmjmilitary-2020-001692

Szendrői Miklós (szerk.): Ortopédia. Budapest, Semmelweis, 2005.

Taanila, Henri - Jaana Suni - Harri Pihlajamäki - Ville M. Mattila - Olli Ohrankämmen - Petteri Vuorinen -Jari Parkkari: Musculoskeletal Disorders in Physically Active Conscripts: A One-Year Follow-Up Study in the Finnish Defence Forces. BMC Musculoskeletal Disorders, 10. (2009), 1. 1-11. Online: https://doi. org/10.1186/1471-2474-10-89

Valdes, A. M. - Tim D. Spector: Genetic Epidemiology of Hip and Knee Osteoarthritis. Nature Reviews Rheumatology, 7. (2011), 1. 23-32. Online: https://doi. org/10.1038/nrrheum.2010.191

Wikstrom, Erik A. - Mark D. Tillman - Kai J Kline - Paul A Borsa: Gender and Limb Differences in Dynamic Postural Stability during Landing. Clinical Journal of Sports Medicine, 16. (2006), 4. 311-315. Online: https://doi.org/10.1097/00042752200607000-00005

Winby, C. R. - D. G. Lloyd - T. F. Besier - T. B. Kirk: Muscle and External Load Contribution to Knee Joint Contact Loads during Normal Gait. Journal of Biomechanics, 42. (2009), 14. 2294-2300. Online: https://doi.org/10.1016/j.jbiomech.2009.06.019

Witvrouw, Erik - Johan Bellemans - Roeland Lysens - Lieven Daneels - Dirk Cambier: Intrinsic Risk Factors for the Development of Patellar Tendinitis in an Athletic Population. A Two-Year Prospective Study. The American Journal of Sports Medicine, 29. (2001), 2. 190-195. Online: https://doi.org/10.1177/03635465010290021201

Witvrouw, Erik - Lieven Danneels - Peter Asselman - Thomas D'Have - Dirk Cambier: Muscle Flexibility as a Risk Factor for Developing Muscle Injuries in Male Professional Soccer Players. A Prospective Study. The American Journal of Sports Medicine, 31. (2003), 1. 41-46. Online: https://doi.org/10.1177/03635465030310011801

Witvrouw, Erik - Roeland Lysens - Johan Bellemans - Dirk Cambier - Guy Vanderstraeten: Intrinsic Risk Factors for the Development of Anterior Knee Pain in an Athletic Population. A Two-Year Prospective Study. The American Journal of Sports Medicine, 28. (2000), 4. 480-489. Online: https://doi.org/10.1177/0363 5465000280040701

Woo, Savio L. - J. Marcus Hollis - Douglas J. Adams - Roger M. Lyon - Shinro Takai: Tensile Properties of the Human Femur-Anterior Cruciate Ligament-Tibia Complex: The Effects of Specimen Age and Orientation. The American Journal of Sports Medicine, 19. (1991), 3. 217-225. Online: https://doi.org/10.1177/036354659101900303

Young, Jodi L. - Suzanne J. Snodgrass - Joshua A. Cleland - Daniel I. Rhon: Usual Medical Care for Patellofemoral Pain Does Not Usually Involve Much Care: 2-Year Follow-up in the Military Health System. Journal of Orthopaedic \& Sports Physical Therapy, 51. (2021), 6. 305-313. Online: https://doi.org/10.2519/jospt.2021.10076 